\title{
INTRAPERSONAL CONFLICT AT THE JUNCTION OF CONFLICTOLOGY, PRACTICAL AND CLINICAL PSYCHOLOGY
}

Petrunko Olga, Doctor Degree in Psychology, Senior Researcher, Professor of the Department of Psychology,

HEI «Institute of Economics and Law «KROK»,

30-32 Lagerna Str., 03113 Kyiv, Ukraine, Petrynko@rambler.ru

The article shows the essence of interpersonal conflicts. This conflict considered as problematic for its carrier state that: 1) is extremely important, and certainly associated with the choice between alternatives equal in strength for him (even if the alternatives are not understood); 2) subjectively experienced as a insoluble problem and so is extremely, uncomfortable, tense, frustration and painful feelings about their inferiority; 3) tends to deepen, strengthening, totalization and no adaptive course. Analyzed and summarized a some number of scientific concepts about interpersonal conflicts and understanding of its basic type described in professional literature. The features of the subject of interpersonal conflict in conflictology, total, practical and clinical psychology are shown and the model of interdisciplinary study this conflicts are proposed. The attention to constructive (adaptive) and unconstructive (no adaptive) intrapersonal conflicts is accented. The features of intrapersonal conflicts in the area of the individual motivation are shown. Particular attention is paid to motivating interpersonal conflicts with non-adaptive and destructive forms of current. Features of no adaptive motivational conflict and possible consequences of these conflicts for intrapersonal and interpersonal (social) life of a person are shown.

Keywords: criteria for non-adaptive conflict; interdisciplinary subject of conflict; intrapersonal conflict; intrapersonal reality; non-adaptive motivational conflict.

Стаття надійшла до редакції 27.01.2017

Прийнято до друку 23.03.2017

УДК 159.923:37.091.12

Інна Власенко

ORCID iD 0000-0003-2562-3637

кандидат психологічних наук, викладач кафедри загальної, вікової та педагогічної психології Інституту людини, Київський університет імені Бориса Грінченка, просп. П. Тичини, 17, 02152 м. Київ, Україна

i.vlasenko@kubg.edu.ua

\section{ВНУТРІШНЬООСОБИСТІСНІ КОНФЛІКТИ ВЧИТЕЛІВ: МОТИВАЦІЙНИЙ АСПЕКТ}

\footnotetext{
У статті розглянуто мотиваційний аспект внутрішньоособистісних конфліктів сучасних вчителів. Встановлено, що у мотиваційно-особистісній сфері досліджуваних домінують екзистениійні та індивідуальні цінності. Виявлено, що одна п'ята частина педагогів невдоволена поточною життєвою ситуацією, проявляє внутрішню конфліктність. Відчуття внутрішньої конфліктності та нереалізованості в одній з головних життєвих сфер («щасливе сімейне життя», «здоров'я», «любов») супроводжується у вчителів високою внутрішньою конфліктністю в інших важливих сферах.
}

Ключові слова: внутрішньоособистісний конфлікт; вчителі; мотиваційно-особистісна сфера; иінності.

Вступ. Реформування освітньої системи Украіни висуває нові вимоги не тільки до рівня професійних знань і умінь вчителя, але і його особистості. В ситуації підвищення складності спілкування з учнями в умовах сучасної школи значна частина педагогів стикаються з внутрішніми суперечностями і конфліктами, які не тільки не сприяють пошуку продуктивних шляхів розв'язання професійних завдань, але й перешкоджають отриманню вчителем задоволення від своєї діяльності, спілкування і життя загалом. Загальне підвищення соціальної напруженості, суттєві зміни в системі суспільних та індивідуальних цінностей зумовлюють зростання конфліктності у стосунках суб'єктів навчально-виховного процесу, а також підвищення внутрішньої дисгармонії вчителя, що виявляється у формі внутрішньоособистісних протиріч та конфліктів. 
Психологічні дослідження особистості та діяльності вчителя вказують на наявність суперечностей між потребою вчителів у самореалізації та загостренням їх внутрішніх конфліктів, між необхідністю конструктивного подолання згаданих конфліктів і недостатньою компетентністю педагогів у цій специфічній сфері знань та умінь.

Загальнотеоретичні аспекти проблеми внутрішньоособистісних конфліктів окреслено в роботах зарубіжних (А. Адлер, К. Левін, Л. Фестінгер, К. Юнг та інші), радянських (К. О. Абульханова-Славська, Л. І. Божович, Ф. Є. Василюк, В. С. Мерлін, В. М. Мясищев) та українських психологів (О. Ф. Бондаренко, О. А. Донченко, Т. М. Титаренко, В. М. Чернобровкін та інші).

Встановлено, що лише окремі аспекти внутрішньоособистісних конфліктів учителів стали предметом досліджень науковців. Так, вивчались особливості подолання вчителями внутрішньоособистісних конфліктів (Маланьїна Т. М., 2011), специфіка їх психодіагностики та корекції у зв'язку з професійним вигоранням педагогів (Березовська Л. І., 2013). Зарубіжні автори досліджували явища, пов’язані з внутрішньоособистісними конфліктами вчителів: рольовий конфлікт, що в комплексі з іншими факторами може спричинити плинність вчительських кадрів (Tiplic D. et al., 2016), конфлікт між робочими та сімейними ролями у педагогів (Palmer M. et al., 2012). Японські автори (Nakada, A. et al., 2016) довели зв'язок між депресивними симптомами й індивідуальним рівнем професійного стресу в педагогів та виявили, що 20,1\% вчителів належать до депресивної групи.

Водночас досліджень психологічних особливостей прояву внутрішньоособистісних конфліктів у мотиваційній сфері учителів не виявлено, тоді як знання та врахування таких особливостей психологічною службою, керівництвом школи сприятиме усуненню наявних конфліктів.

Мета статті - з'ясувати психологічні особливості прояву внутрішньоособистісних конфліктів у мотиваційній сфері вчителів.

Внутрішньоособистісні конфлікти вчителів. Нами було проведено дослідження особливостей прояву внутрішньоособистісних конфліктів у мотиваційній сфері учителів. Дослідницька робота виконувалась у 2013-2014 рр. на базі тринадцяти загальноосвітніх та спеціалізованих шкіл міст Києва, Звенигородки Черкаської області, смт. Калинівки Київської області. Також до дослідження було залучено педагогів, які проходили курсову перепідготовку при Київському університеті імені Бориса Грінченка. Вибірку склали 192 вчителів віком від 19 до 70 років (89,6\% жінок та 10,4\% чоловіків).

Для виявлення мотиваційного аспекту внутрішньоособистісних конфліктів учителів нами використано методику «Рівень співвідношення «цінності» й «доступності» в різних життєвих сферах» (Фанталова О. Б., 1997). В основі методики лежить припущення про те, що суттєвою детермінантою мотиваційної сфери особистості є змінюване в процесі діяльності і під впливом життєвих обставин співвідношення між двома площинами «свідомості». А саме: між площиною, що включає усвідомлення провідних життєвих цінностей, особистісних смислів, віддалених життєвих цілей, і площиною всього безпосередньо доступного, пов'язаного із втіленням конкретних, легко досяжних цілей.

Основною психометричною характеристикою методики є показник «цінність - доступність» («Ц-Д»), що відображає ступінь розузгодження, дезінтеграції в мотиваційно-особистісній сфері, яку трактуємо як показник внутрішньоособистісного конфлікту вчителя. Така дезінтеграція свідчить про ступінь незадоволення поточною життєвою ситуацією, внутрішню конфліктність, а також, з іншого боку - про рівень самореалізації, внутрішньої ідентичності, інтегрованості. Згідно з уявленнями О. Б. Фанталової, інтегральний показник методики - індекс розходження «Ц-Д» - виступає індикатором блокади ціннісно-смислових утворень, а також індикатором внутрішніх конфліктів у мотиваційно-особистісній сфері (Фанталова О. Б., 1997 , с. 7-8). Величина зазначеного індексу вказує на ступінь розходження між тим, що є, і тим, що, на думку обстежуваного, повинно бути, між тим, чого суб'єкт хоче і що має, а також між тим, чого він хоче і що може.

Стосовно конкретної життєвої сфери показник розходження між цінним і безпосередньо доступним (Ц і Д) має двовимірну характеристику. Максимальне розходження між Ц і Д у випадку, коли «цінне» перевищує «доступне» (різниця між ними більше) дорівнює 4), свідчить про стійкий, глибокий, до нинішнього часу незворотний внутрішній конфлікт. Співвідношення, коли «доступне» перевищує «цінне» (різниця між ними більше/дорівнює 4), навпаки, означає стан «внутрішнього вакууму», внутрішньої спустошеності, зниження спонукань.

При аналізі результатів дослідження кількісних i якісних показників внутрішньоособистісних конфліктів у мотиваційній сфеpi вчителів ми виявили індекс розходження «цінності - доступності» («Ц-Д»), що вважається індикатором внутрішніх конфліктів у мотиваційно-особистісній сфері (Фанталова О. Б., 1997). 3'ясовано, що 81 вчитель (42,2\% досліджуваних) характеризується низьким рівнем індексу розходження «Ц-Д», 71 (37\% респондентів) середнім і 40 вчителів (20,8\% респондентів) - високим. Це означає, що більше 40\% педагогів відзначаються високим рівнем самореалізації, внутрішньої ідентичності. Виявлено, що 20,8\% педагогів виявляють високий ступінь незадоволення поточною життєвою ситуацією, внутрішню конфліктність. Отримані нами дані співвідносяться з результатами японських дослідників про депресивні прояви в учителів (Nakada A., et al., 2016). Понад третина 
вчителів має нестійку рівновагу в мотиваційно-особистісній сфері (внутрішньоособистісні протиріччя), що періодично викликає відчуття внутрішнього дискомфорту, невдоволеності власним життям.

Дезінтеграція в мотиваційно-особистісній сфері потенційно може стимулювати індивіда до подолання неконструктивного стану, розширення способів та форм поведінки, діяльності, спілкування, а з іншого боку - може стримувати особистісний та професійний розвиток. Життєві сфери педагогів проранговано за «цінністю» і «доступністю»: 3 підвищенням цих показників їх ранги зростають і навпаки. Середьногрупові ранги «цінності» та «доступності» щодо основних життєвих сфер у вчителів показано на рисунку. Аналіз отриманих даних дав змогу встановити, що у мотиваційно-особистісній сфері вчителів домінують екзистенційні та індивідуальні цінності.

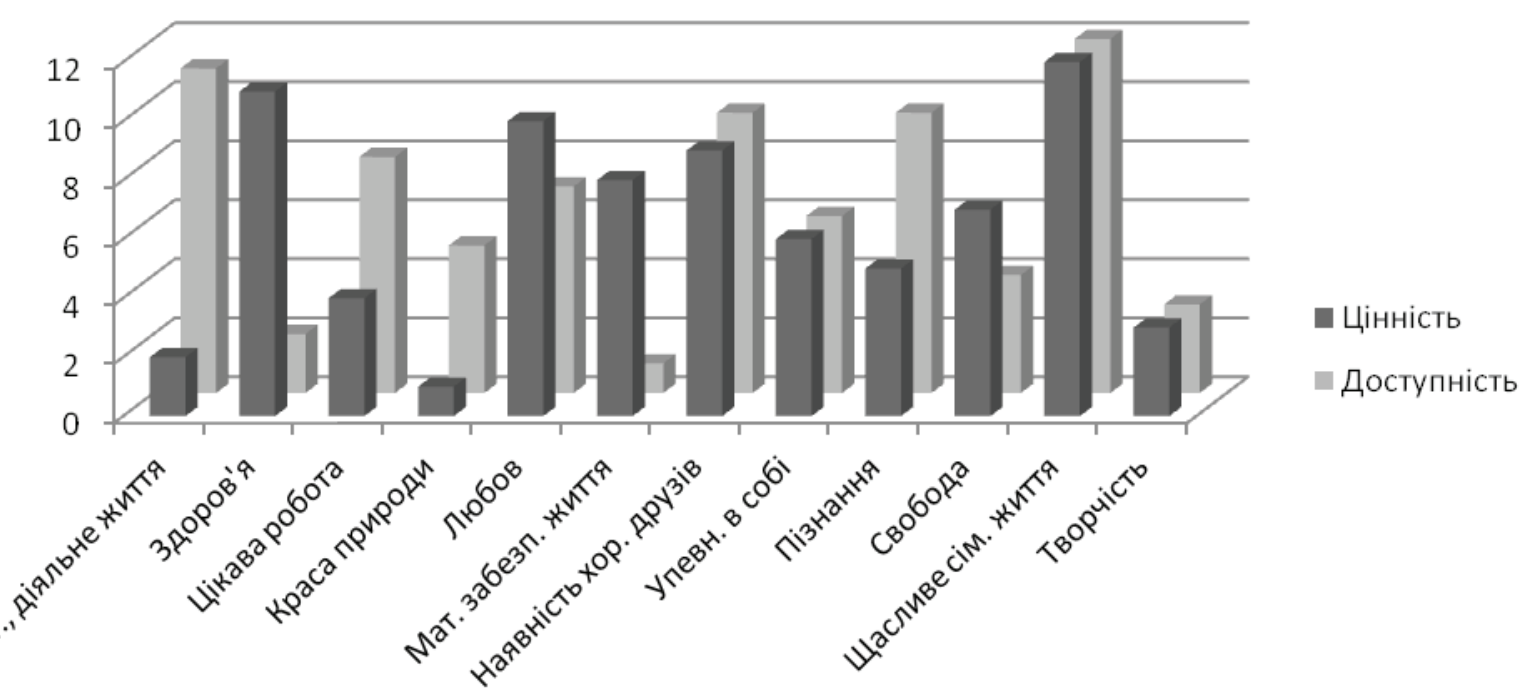

Рис. 1 Середньогрупові ранги «цінності» та «доступності» щодо основних життєвих сфер у вибірці вчителів, $\mathrm{n}=192$

За показниками «цінності» виділено чотири групи життєвих сфер, що мають різну значущість для вчителів. Як видно із рис., найвищими рангами у структурі життєвих сфер вчителів (Ц і Д показано в дужках) характеризуються: щасливе сімейне життя (Ц12; Д12); здоров’я (Ц11; Д2); любов (Ц10; Д7) - перша за значущістю група. Друга група життєвих сфер представлена такими: наявність хороших і вірних друзів (Ц9; Д9,5); матеріально забезпечене життя (Ц8; Д1); свобода (Ц7; Д4); третя група значущих життєвих сфер об'єднує наступні: впевненість у собі (Ц6; Д6); пізнання (Ц5; Д9,5); цікава робота (Ц4; Д8). Четверту групу значущих життєвих сфер представляють: творчість (Ц3; Д3); активне, діяльне життя (Ц2; Д11); краса природи і мистецтва (Ц1; Д5). Очевидно, висока значущість загальнолюдських цінностей у вибірці пов'язана із прагненням вчителя зберегти ідентичність в умовах суспільної нестабільності, під тиском загальної глобалізації, крос-культурних впливів, наступу маскультури.

Вагомим є переважання вчителів жіночої статі, для яких традиційно значущими є цінності сімейного життя, спілкування, взаємодопомоги, підтримки.

Аналіз загальної структури ціннісних сфер і місця в ній цінностей індивідуального вдосконалення (пізнання, цікава робота, творчість, активне, діяльне життя), ймовірно, свідчить про те, що для частини вчителів прагнення до підвищення професіо- налізму, ерудованості втрачають актуальність, що може бути пов'язано з переорієнтацією їніх інтересів з області професійної діяльності на інші сфери. В умовах посиленого зовнішнього і внутрішнього контролю у педагогів нерідко розвивається нервове перенапруження.

3'ясовано також змістові характеристики внутрішньоособистісних конфліктів учителів. Так, у мотиваційно-особистісній сфері найчастіше виявляються внутрішні конфлікти у сферах «здоров'я» (47,9\% - 92 опитуваних), «щасливе сімейне життя» (33,9\% - 65 респондентів), «матеріально забезпечене життя» і «любов» $(27,1$ та 26\% - 52 i 50 опитуваних відповідно). Згадані сфери представляють найбільш афективно заряджені частини самосвідомості вчителів.

Для з'ясування особливостей прояву внутрішньої конфліктності вчителів звернемось до аналізу внутрішніх вакуумів. Останні відзначаються зниженням спонукань (Фанталова О. Б., 1997), а отже смислового наповнення певної життєвої сфери, що зумовлює зниження активності вчителя, а відповідно, і його можливості подолати внутрішньоособистісний конфлікт. Виявлено найбільш виражені внутрішні вакууми у сферах «активне, діяльне життя» $(50,5 \%$ - 97 респондентів), «краса природи та мистецтва» (44,8\% - 86 опитуваних), «цікава робота» $(27,1 \%$ - 52 респонденти), «пізнання» $(22,9 \%$ 44 опитуваних). 
Внутрішній вакуум у сфері «активне, діяльне життя» може свідчити про так зване «перенасичення» індивіда активною діяльністю. Внутрішній вакуум у сфері «краса природи і мистецтва», ймовірно, пов'язаний із впливом на свідомість педагога ідеології споживання. Понад 40\% вчителів недостатньо цінують красу, незважаючи на їі потенціал як джерела розвитку і саморозуміння. Внутрішні вакууми у сферах «цікава робота» $\mathrm{i}$ «пізнання» у респондентів можемо трактувати як знижене прагнення до інтелектуальних, духовних зусиль, пошуків, що пов'язане, на нашу думку, з рольовим перевантаженням вчителів, виконанням різнопланових і складних ролей (від підлеглого до лідера, від вчителя до жінки і матері). Вважаємо, що такі внутрішні вакууми вказують на перенапруження учителя, виснаження його психологічних ресурсів у зв'язку 3 стресонасиченістю його діяльності і високими професійними вимогами.

Також ми прагнули виявити, наскільки узгоджено змінюються у досліджуваних групові ієрархії ознак (показник розузгодження між «цінним» та «доступним» (Ц-Д) за кожною життєвою сферою). 3 цією метою ми з'ясували за допомогою критерію рангової кореляції Спірмена вираженість кореляційних зв'язків розузгодження між «цінним» та «доступним» за кожною життєвою сферою. Відповідний показник набував значень від -11 до 11, що вказувало на вираженість внутрішніх вакуумів (коли Ц<Д) та внутрішніх конфліктів (Ц>Д) у вчителів.

Виявлено, що чим більша розбіжність між «цінним» $\mathrm{i}$ «доступним» у сфері «здоров'я», тим більш виражене у досліджуваних відчуття внутрішньої конфліктності у сферах «щасливе сімейне життя» $\left(\mathrm{r}_{\mathrm{s}}=0,295, \mathrm{p} \leq 0,01\right)$ та «матеріально забезпечене життя» $\left(\mathrm{r}_{\mathrm{s}}=0,286, \mathrm{p} \leq 0,01\right)$, а також більш виражене відчуття внутрішнього вакууму (перенасиченості) у сферах «пізнання» $\left(\mathrm{r}_{\mathrm{s}}=-0,375, \mathrm{p} \leq 0,01\right)$ «творчість» $\left(\mathrm{r}_{\mathrm{s}}=-0,370, \mathrm{p} \leq 0,01\right)$, «осягнення краси» $\left(r_{\mathrm{s}}=-0,297, \mathrm{p} \leq 0,01\right)$.

\section{Література}

1. Березовська Л. І. Психодіагностика та корекція внутрішньоособистісних конфліктів як умова подолання професійного вигоряння вчителів: автореф. ... канд. психол. наук: 19.00 .10 / Л. І. Березовська. - К., 2013. $-21 \mathrm{c}$.

2. Маланьїна Т. М. Психологічні особливості подолання вчителями внутрішньоособистісних конфліктів: автореф. дис... канд. психол. наук: 19.00 .07 / Тетяна Михайлівна Маланьїна. - К., 2011. - 20 с.

3. Фанталова Е. Б. Диагностика внутриличностного конфликта / Е. Б. Фанталова. - М.: Фолиум, 1997. $-48 \mathrm{c}$.

4. Nakada, A., Iwasaki S., Kanchika, M. et al. Relationship between depressive symptoms and perceived individual level occupational stress among Japanese schoolteachers. INDUSTRIAL HEALTH, 2016, Vol. 54, no. 5, 396-402.

5. Palmer M., Rose, D., Sanders, M., Randle, F. Conflict between work and family among New Zealand teachers with dependent children. Teaching and teacher education, 2012, Vol. 28, no. 7, 1049-1058, DOI: 10.1016/j.tate.2012.05.002.

6. Tiplic D., Brandmo C., Elstad E. Antecedents of Norwegian Beginning Teachers' Turnover Intentions. Cambridge Journal Of Education, 2015, Vol. 45, no. 4, 451-474, DOI: 10.1080/0305764X.2014.987642. 


\section{References}

1. Berezovsjka L. I. (2013). Psykhodiaghnostyka ta korekcija vnutrishnjoosobystisnykh konfliktiv jak umova podolannja profesijnogho vyghorjannja vchyteliv [Psychodiagnostics and correction of intrapersonal conflicts as condition of teachers' professional burnout overcoming]: Extended abstract of candidate's thesis: 19.00.10. K., 21 (ukr).

2. Malanjjina T. M. (2011). Psykhologhichni osoblyvosti podolannja vchyteljamy vnutrishnjoosobystisnykh konfliktiv [Psychological peculiarities of teachers' intrapersonal conflicts overcoming]: Extended abstract of candidate's thesis: 19.00.07. K., 20 (ukr).

3. Fantalova E. B. (1997). Diagnostika vnutrilichnostnogo konflikta [Psychodiagnostics of intrapersonal conflict]. M.: Folium, 48 (rus).

4. Nakada A., Iwasaki S., Kanchika M. et al. (2016). Relationship between depressive symptoms and perceived individual level occupational stress among Japanese schoolteachers. INDUSTRIAL HEALTH, 54 (5), 396-402 (eng).

5. Palmer M., Rose D., Sanders M., Randle F. (2012). Conflict between work and family among New Zealand teachers with dependent children. Teaching and Teacher Education, 28 (7), 1049-1058, DOI: 10.1016/j. tate.2012.05.002 (eng).

6. Tiplic D., Brandmo C., Elstad E. (2015). Antecedents of Norwegian Beginning Teachers' Turnover Intentions. Cambridge Journal Of Education, 45 (4), 451-474, DOI: 10.1080/0305764X.2014.987642 (eng).

\section{ВНУТРИЛИЧНОСТНЫЕ КОНФЛИКТЫ УЧИТЕЛЕЙ: МОТИВАЦИОННЫЙ АСПЕКТ}

Власенко Инна, кандидат психологических наук,

преподаватель кафедры общей, возрастной и педагогической психологии Института человека, Киевский университет имени Бориса Гринченко,

просп. П. Тычины, 17, 02152 г. Киев, Украина, i.vlasenko@kubg.edu.ua

В статье рассмотрен мотивационный аспект внутриличностных конфликтов современных учителей. Установлено, ито в мотивационно-личностной сфере исследуемых доминируют экзистенциальные и индивидуальные ценности. Выявлено, что пятая часть педагогов недовольны текущей жизненной ситуацией, пролвляют внутреннюю конфликтность. Ощущение внутренней конфликтности и нереализованности в одной из главных жизненных сфер («счастливая семейная жизнъ», «здоровъе», «любовь») сопровождается $у$ учителей высокой внутренней конфликтностью в других важных сферах.

Ключевые слова: внутриличностный конфликт; мотивачионно-личностная сфера; учителя; ценности.

\section{TEACHERS' INTRAPERSONAL CONFLICTS: MOTIVATIONAL ASPECT}

Vlasenko Inna, Ph.D. in Psychology, Lecturer of Department of General, age and educational psychology of Institute of Human Sciences, Borys Grinchenko Kyiv University, 17 Tychyny Ave., 02152 Kyiv, Ukraine, i.vlasenko@kubg.edu.ua

This study aims at exploring psychological peculiarities of teachers' intrapersonal conflicts in manifestation motivational sphere. The sample consists of 192 teachers (89,6\% female and 10,4\% male) from 13 schools in Ukraine. It is presented the analyses of internal conflicts and vakuums in motivational sphere of teachers. The results show existential and individual values prevail in respondents'motivational sphere. It was found that $42,2 \%$ of teachers had a low discoordination among things they want and need on the one hand and their possibilities on the other. It was found that 20,8\% of teachers wasn't satisfied with their current life situation, had an internal conflict. The feeling of internal conflict and low ability to self-actualization in one of teachers' main life spheres ( life», «health», «love») were connected with high internal conflict in other life spheres of teachers. There have been identified internal conflicts in the spheres of «health» (47,9\% respondents), «happy domestic life» (33,9\%), «inancial provided life» $(27,1 \%)$ and «love» (26\% teachers). It was investigated high internal vakuums in spheres «active life» $(50,5 \%)$, «interesting work» (27,1\% respondents) that indicated reducing of motivation and could lead to teachers' activity declining. Teachers that have high level of internal vakuums feel exhausted and overstressed as well as they face to high professional demands. A programme addressing intrapersonal conflict and managing low ability to self-actualization in main life spheres would be of benefit to teachers.

Keywords: intrapersonal conflict; motivational sphere; teachers; values.

Стаття надійшла до редакції 23.02.2017 Прийнято до друку 23.03.2017 